\title{
QUALI/QUANTITATIVE CHARACTERIZATION OF BIOGAS PRODUCED IN BATCH DIGESTERS SUPPLIED WITH SIX DISTINCT SUBSTRATES
}

\author{
JOÃO A. GALBIATTI ${ }^{1}$, ANAIRA D. CARAMELO ${ }^{2}$, DENISE A. CHICONATO ${ }^{3}$, \\ JOSÉ R. ARAÚJO ${ }^{4}$, ELIANA A. B. GIRARDI ${ }^{5}$
}

\begin{abstract}
The present research was carried out at the DER/FCAV, São Paulo State University - Brazil, with the purpose of analyzing the quantity and quality of biogas produced by six types of substrates. The substrates used in the anaerobic digestion were characterized as: 1- Litter of broiler (LB); 2- Grinded broiler litter (GBL); 3- Broiler litter with wood shavings (BLWS); 4- Grinded broiler litter with wood shavings (GBLWS); 5- Broiler litter with peanut hulls (BLPH); 6- Grinded broiler litter with peanut hull (GBLPH). It was concluded from the collected data that: the (GBL) substrate showed a superior biogas accumulated production in relation to the other substrates, while the BLWS presented an inferior accumulated production; the grinded substrates showed higher quantities of accumulated biogas in relation to the non-grinded substrates, except for GBLPH, with $20.9 \mathrm{~m}^{3}$ inferior than BLPH; the period of maximum biogas production started from 45 to 60 days, declining after 120 days; at 57 days after filling up the digesters the biogas produced had levels of $\mathrm{CH}_{4}$ superior than $53 \%$, and from 99 days all of them produced biogas with levels of $\mathrm{CH}_{4}$ superior than 70\%; LB and GBL presented higher concentrations of $\mathrm{CH}_{4}$ in the biogas.
\end{abstract}

KEYWORDS: biogas, anaerobic, organic residue, digesters.

\section{CARACTERIZAÇÃO QUALI/QUANTITATIVA DO BIOGÁS PRODUZIDO EM BIODIGESTORES DE BATELADA ALIMENTADOS COM SEIS SUBSTRATOS DISTINTOS}

RESUMO: Com a finalidade de se analisar quali/quantitativamente o biogás produzido por 6 tipos de substratos, efetuou-se a presente pesquisa no DER/FCAV/UNESP- SP, Brasil. Os substratos utilizados na digestão anaeróbia foram caracterizados como: 1- Esterco de aves de postura (EAP); 2- Esterco de aves de postura triturado (EAPT); 3- Esterco de aves de corte com cama de maravalha (EACM); 4- Esterco de aves de corte com cama de maravalha triturado (EACMT); 5- Esterco de aves de corte com cama de casca de amendoim (EACA), e 6- Esterco de aves de corte com cama de casca de amendoim triturado (EACAT). Dos resultados obtidos, concluiu-se que, em relação à produção acumulada de biogás, o substrato EAPT foi superior aos demais, enquanto EACM apresentou produção acumulada inferior. Em geral, os substratos triturados apresentaram maior quantidade de biogás acumulado em relação aos não triturados, exceto o EACAT, com $20,9 \mathrm{~m}^{3}$ inferior ao EACA. O período de produção máxima de biogás teve início entre 45 e 60 dias, começando a decair a partir dos 120 dias. Aos 57 dias após o enchimento dos biodigestores, o gás produzido possuía teores de $\mathrm{CH}_{4}$ superiores a 53\%, e a partir dos 99 dias, todos produziram biogás com teores de $\mathrm{CH}_{4}$ superiores a $70 \%$. Os substratos EAP e EAPT apresentaram maiores concentrações de metano no biogás.

PALAVRAS-CHAVE: biogás. anaeróbio. resíduos orgânicos. biodigestores.

\footnotetext{
${ }^{1}$ Eng $^{\circ}$ Agrônomo, Prof. Doutor, FCAV/UNESP, Jaboticabal - SP, galbi@ fcav.unesp.br.

${ }^{2}$ Bióloga, Doutoranda em Ciência do Solo, Depto. de Eng. Rural, FCAV/UNESP, Jaboticabal-SP, anairacaramelo@yahoo.com.br.

${ }^{3}$ Bióloga, Mestranda em Produção Vegetal, Depto. de Engenharia Rural, FCAV/UNESP, Jaboticabal - SP, denise.ac@hotmail.com.

${ }^{4}$ UNIFEB, jaraujo@feb.br.

${ }^{5}$ UNIFEB.

Recebido pelo Conselho Editorial em: 23-6-2009
}

Aprovado pelo Conselho Editorial em: 20-4-2011 


\section{INTRODUCTION}

The supply of energy components is directly related to a nation's development (SOUZA et al., 2010). According to data from the National Energy Balance for the year 2004, the main sources of energy for consumption in the agricultural sector were diesel oil (58\%), firewood (26\%), electricity $(15 \%)$ and other sources (1\%) (BRASIL, 2005).

During the period 2002-2004, official data showed rising prices paid for energy, since the price of diesel increased $41 \%$, firewood increased 52\%, and electricity increased 36\%, on average.

The impact of rising energy costs is felt more strongly in the rural sector with the lowest incomes, generally less capitalized and less able to afford higher energy costs, both in respect to domestic consumption and for activity production (ESPERANCINI, 2007).

Productivity, efficiency, profitability and sustainability are issues that need to be considered in the current period of the production process in Brazil (SANTI et al., 2010). A strategy for the development of a particular activity, without more commitment of energy reserves and the environment, caused by improper disposal of waste generated in production systems, is to use these systems for recycling waste, thus promoting the generation of energy by using renewable sources (AMORIM et al., 2004).

In this sense, the development and implementation of alternative technologies for power generation at low cost for this segment can generate positive economic impact.

The use of biomass is one of the most promising technological alternatives with respect to energy generation (GALBIATTI et al., 2010).

One of the conversion processes of biomass energy is anaerobic digestion. This digestion is natural, with a fermentation process where anaerobic microorganisms produce biogas, which can be directly used as a source of energy in burners or engines generators (XAVIER \& LUCAS JR., 2010) and it also has the advantage of contributing to the solution of environmental problems, because it substitutes fossil fuels (LORA \& ANDRADE, 2009).

The biogas composition varies depending on the substrate used in the production process. Some gases can, to a lesser concentration, compose the biogas, such as hydrogen sulfide, nitrogen, hydrogen and carbon monoxide; however, its main constituents are methane $(60-80 \% \mathrm{v} / \mathrm{v})$ and carbon dioxide (20-40\% v/v) (SOUZA et al., 2010). Methane is the main component of biogas and different percentages can be obtained by using various raw materials (PRADO \& CAMPOS, 2008).

The calorific value of biogas is variable, from approximately 22,500 to $25,000 \mathrm{~kJ} \mathrm{~m}^{-3}$, assuming methane with about $35,800 \mathrm{~kJ} \mathrm{~m}^{-3}$. This means the use of 6.25 to $10 \mathrm{kWh} \mathrm{m}^{-3}$ (SALOMON et al., 2007). Its potential is demonstrated when biogas is treated $\left(\mathrm{CO}_{2}\right.$ removal), as its calorific value can reach $60 \%$ that of natural gas. Therefore, one should analyze the substrates for biogas producers, not only for the volume of biogas produced, but also for its quality.

ROSS et al. (1996) reported that the pure methane at normal temperature and pressure shows calorific value of about $33,980 \mathrm{~kJ} \mathrm{~m}^{-3}$. Biogas, with $65 \%$ methane, has calorific value of approximately $22,353 \mathrm{~kJ} \mathrm{~m}^{-3}$, because only the methane will burn. ROSS et al. (1996) also indicates that $1 \mathrm{~m}^{-3}$ of biogas with $65 \%$ of methane is equivalent to $0.6 \mathrm{~m}^{-3}$ of natural gas, 0.882 liters of propane, 0.789 liters of butane, 0.628 liters of gasoline, 0.575 liters of fuel oil, $0.455 \mathrm{~kg}$ of bituminous coal and $1.602 \mathrm{~kg}$ of dry wood.

The poultry industry is an activity with intense energy consumption, but it also has the characteristic of producing waste with considerable energy potential, such as poultry litter, which can contribute to the energy balance in operations developed inside the shed when processed in order to provide energy. 
The Brazilian poultry industry produced in 2007 approximately eight million tons of meat, corresponding to $16.4 \%$ of the world production, with exportation of 1.8 million tons and an increasing participation of Brazil to almost a third of total foreign trade (ORRICO JR. et al., 2010).

Specifically for rural areas in Brazil, some models of anaerobic digesters have proven of interest mainly because they have lower costs due to associated low technology and simple operation. An anaerobic digester model is the batch digester, where the treatment of organic solid waste can be accomplished with a high concentration of solids, with an average of $20 \%$ (percentage by weight) of total solids in the substrate (LUNA et al., 2009).

Bird carcasses have high potential for methane production; however, they are modestly used in biogas production because of the difficulty of handling and the need of specific anaerobic digestion systems (ORRICO JR. et al., 2010).

The objective of this work was to verify the quality and quantity of biogas data, essential to its use, in order to obtain a clear understanding of the variation behavior of its components during the fermentation process, thus allowing to observe and characterize possible variations, as well as to control the quality of the gas to be purified and stored.

\section{MATERIAL AND METHODS}

The experiment was conducted at the Department of Agricultural Engineering, College of Agricultural Sciences and Veterinary, belonging to São Paulo State University (UNESP) and located in the municipality of Jaboticabal, at the latitude $21^{\circ} 15^{\prime} 22^{\prime \prime} \mathrm{S}$, longitude $48^{\circ} 18^{\prime} 58^{\prime \prime} \mathrm{W}$ and an altitude of 575 meters. For the development of this research, were used 24 batch digester units with 70-liter capacity each. The digesters were made of basically two straight circular cylinders, one of which was placed inside the other so that the space between the outer wall of the inner cylinder and the inner wall of the outer cylinder held a volume of water called "water seal", which reached a depth of $50 \mathrm{~cm}$. An inverted bell floating in the "water seal" provided the anaerobic conditions under which the fermentation process developed, and retained the gas produced (Figure 1).

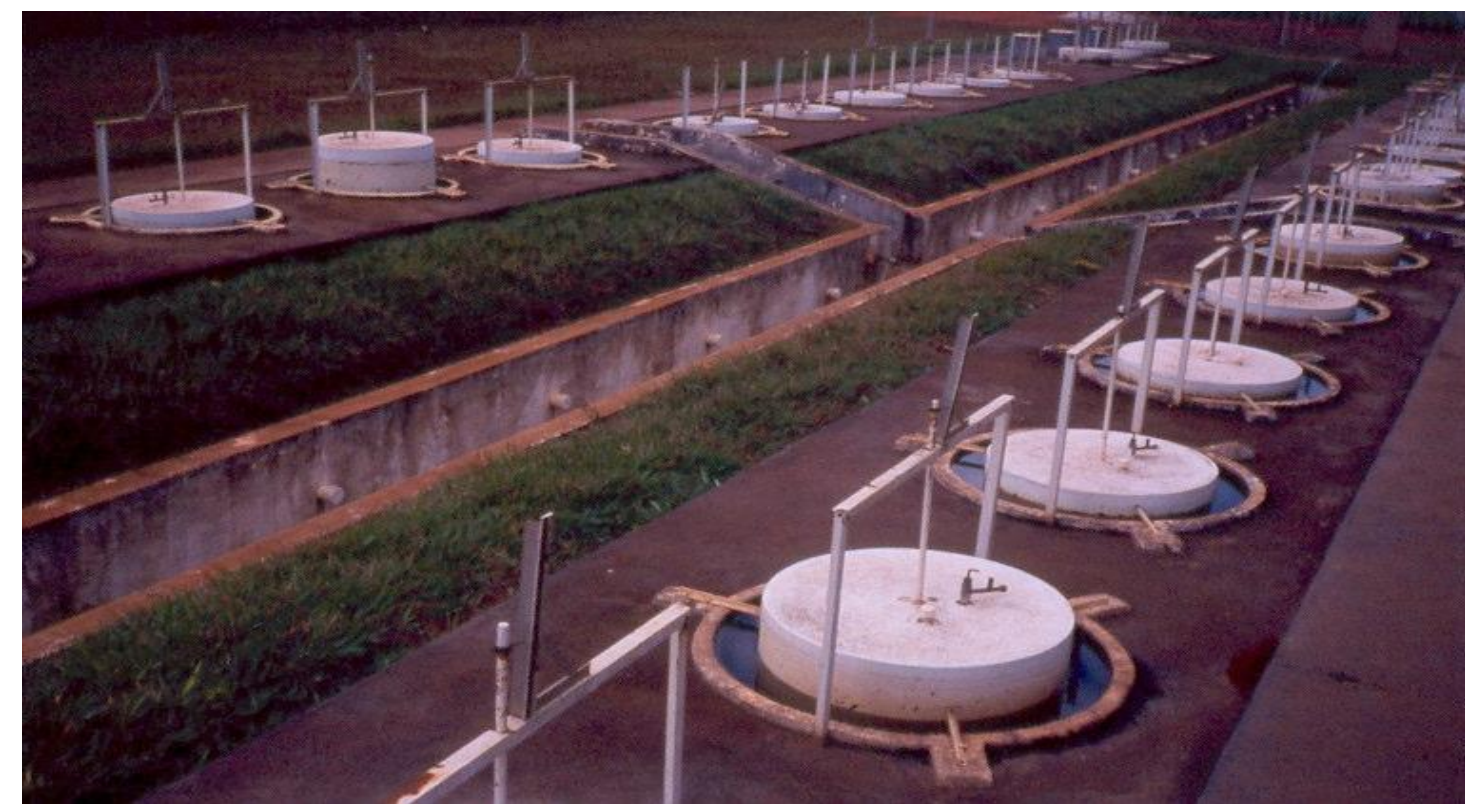

FIGURE 1. Experimental anaerobic digester system.

The substrates used were: 1- Litter of broiler (LB); 2- Grinded broiler litter (GBL); 3- Broiler litter with wood shavings (BLWS); 4- Grinded broiler litter with wood shavings (GBLWS); 5Broiler litter with peanut hulls (BLPH); 6- Grinded broiler litter with peanut hull (GBLPH). The manure used in the composition of the different substrates was collected on farms, with information 
collected on the age of animals, their origin, and composition of the feed supplied to the animals. After collection of substrates, these were characterized regarding particle size by using a device called Granutest, which has several sieves of different mesh sizes. The LB and GBL substrates were litters of HARC-lineage broilers, with about eight and a half months of age and fed with feed that had as ingredients corn, soy, lime and dicalcium phosphate, without addition of any type of antibiotic. The substrates BLWS and GBLWS were litters of 60 days old broilers of Hubba lineage, supplied feed containing corn, soy, lime, dicalcium phosphate and iodized salt. The substrates BLPH and GBLPH were litters of ARBOR-ACRES lineage broilers with 53 days of age, fed a ration consisting of corn, soybeans, meat meal, bone meal, vitamin supplements, and antibiotics. The granulometric data of LB, GBL, BLWS, GBLWS, BLPH and GBLPH are presented in Table 1.

TABLE 1. Granulometric data of LB, GBL, BLWS, GBLWS, BLPH and GBLPH.

\begin{tabular}{ccccccc}
\hline Mesh \# & $(\%)$ LB & $(\%)$ GBL & $(\%)$ BLWS & $(\%)$ GBLWS & $(\%)$ BLPH & (\%) GBLPH \\
\hline 5 & 78.31 & 2.70 & 16.06 & 0.96 & 41.40 & 6.17 \\
10 & 8.62 & 15.07 & 13.07 & 7.42 & 12.75 & 16.28 \\
16 & 5.63 & 27.91 & 21.50 & 28.70 & 18.51 & 26.50 \\
32 & 4.42 & 28.44 & 26.70 & 32.50 & 13.22 & 26.70 \\
48 & 2.04 & 11.11 & 9.10 & 12.10 & 5.62 & 7.53 \\
\hline Background & 0.98 & 14.47 & 12.40 & 18.32 & 8.50 & 16.82 \\
\hline
\end{tabular}

Litter of broiler (LB); Grinded broiler litter (GBL); Broiler litter with wood shavings (BLWS); Grinded broiler litter with wood shavings (GBLWS); Broiler litter with peanut hulls (BLPH); Grinded broiler litter with peanut hull (GBLPH).

Two days before the filling of the digesters, three samples from each type of manure were taken to estimate the average percentage of total solids. The samples were placed in previously cleaned containers, and then placed into an oven with forced air at a temperature of $80{ }^{\circ} \mathrm{C}$ until reaching constant weight. The biomass was taken to the digesters for mixture preparation. We used a previously sanitized container, a scale, drinking water (FCAV/UNESP supply) and a wooden spoon to homogenize the mixture. The container was placed in the scale where the substrates were placed and water was filled until reaching the calculated proportions. The mixture was stirred until it reached good homogenization and immediately placed into the digester.

After filling the digesters, the volume of biogas produced was measured daily by multiplying the daily vertical displacement of the hood area of the internal section of the hood, during 250 days. For biogas collection, a container was made using a glass bottle with $500 \mathrm{ml}$ capacity, which was capped with a rubber stopper, and two openings were left through which two glass tubes with flexible latex tubing at their ends were introduced for sealing the exits with the help of metal clamps. Vacuum was made in the flask to eliminate contaminant gases; the container was taken to the location of biogas collection. The gas sample was collected through the water column manometer at a pressure of $16 \mathrm{~cm}$ of water column. After this, the biogas sample was taken to the Central Laboratory at FCAV/UNESP for the qualitative-quantitative analyses of its components by gas chromatography.

\section{RESULTS AND DISCUSSION}

Data of biogas production in the form of total accumulation and monthly collections are presented in Table 2. From these data, it is observed that the GBL substrate accumulated the highest production $\left(1282.7 \mathrm{~m}^{3}\right)$, while the BLWS substrate cumulated the lowest production $\left(524.4 \mathrm{~m}^{3}\right)$ at the end of the period studied.

In general, the maximum production period of substrates began between 45 and 60 days and started to decline from 120 days after the addition of substrates to the digesters. 
TABLE 2. Average production of biogas: total accumulated (A) and monthly collection (M), in $\mathrm{m}^{3}$.

\begin{tabular}{ccccccccrr}
\hline \multirow{2}{*}{ Substrate } & \multicolumn{8}{c}{ Days After Filling of the Biodigesters } \\
\cline { 2 - 10 } & Production & \multicolumn{1}{c}{30} & 60 & \multicolumn{1}{c}{90} & 120 & 150 & 180 & 210 & 250 \\
\hline LB & M & 27.4 & 424.2 & 477.4 & 157.8 & 55.6 & 34.0 & 13.0 & 7.5 \\
& $\mathrm{~A}$ & 27.4 & 451.6 & 929.0 & 1086.8 & 1142.4 & 1176.4 & 1189.4 & 1196.9 \\
GBL & $\mathrm{M}$ & 34.4 & 536.5 & 549.3 & 119.8 & 19.2 & 12.5 & 8.0 & 3.0 \\
& $\mathrm{~A}$ & 34.4 & 570.9 & 1120.2 & 1240.0 & 1259.2 & 1271.7 & 1279.7 & 1282.7 \\
BLWS & $\mathrm{M}$ & 48.9 & 378.7 & 87.2 & 8.3 & 1.3 & 0 & 0 & 0 \\
& $\mathrm{~A}$ & 48.9 & 427.6 & 514.8 & 523.1 & 524.4 & 524.4 & 524.4 & 524.4 \\
GBLWS & $\mathrm{M}$ & 37.6 & 464.9 & 128.5 & 9.3 & 0.7 & 0 & 0 & 0 \\
& $\mathrm{~A}$ & 37.6 & 502.5 & 631.0 & 640.3 & 641.0 & 641.0 & 641.0 & 641.0 \\
BLPH & $\mathrm{M}$ & 87.5 & 736.6 & 164.4 & 32.7 & 2.7 & 2 & 2.5 & 2.5 \\
& $\mathrm{~A}$ & 87.5 & 824.1 & 988.5 & 1021.2 & 1023.9 & 1025.9 & 1028.4 & 1030.9 \\
GBLPH & $\mathrm{M}$ & 132.4 & 709.5 & 142.3 & 22.9 & 1.4 & 0 & 1.5 & 0 \\
& $\mathrm{~A}$ & 132.4 & 841.9 & 984.2 & 1007.1 & 1008.5 & 1008.5 & 1010.0 & 1010.0 \\
\hline
\end{tabular}

Litter of broiler (LB); Grinded broiler litter (GBL); Broiler litter with wood shavings (BLWS); Grinded broiler litter with wood shavings (GBLWS); Broiler litter with peanut hulls (BLPH); Grinded broiler litter with peanut hull (GBLPH).

When comparing the production of substrates without grinding to the ground substrates at 250 days of accumulated production, it was observed that in most cases, ground substrates produced much more accumulated biogas, except GBLPH, which showed $20.9 \mathrm{~m}^{3}$ less than its corresponding substrate without grinding, BLPH. In all cases, ground substrates showed higher initial production than non-ground substrates, with relatively significant differences, as observed for the LB substrate, with a production of $5.1 \mathrm{~m}^{3}$ at 30 days, whereas GBL resulted in $20.8 \mathrm{~m}^{3}$, a $75.4 \%$ difference. However, the production showed a sharp decline over the course of the digestion time, and so did each of the other ground substrates studied. The explanation lies in the fact that ground substrates present smaller particle diameter, which increases the contact surface with microorganisms, facilitating the decomposition of organic matter.

The substrates GBL and GBLWS presented values 7 and $18.1 \%$ higher than the substrates LB and BLWS, respectively, being these a significant accumulated production of biogas, but from 90 days onwards these substrates showed a decline in production, when non-ground substrates stood out, with the best long-term results, revealing the action of microorganisms breaking down the smaller particles more quickly.

Table 3 presents data of methane content in biogas, determined biweekly during the development of the experiment. From these data, it can be observed that at 57 days after filling the digesters, the gas produced had more than 53\% of methane. From 99 days after filling the digesters, all substrates produced biogas with methane content above $70 \%$. Early in the digestion process, it was observed that methane production is superior in all ground substrates, presenting until the end of production relatively good rates when compared to non-ground substrates, and showing only a non-significant decline. The substrates LB and GBL showed high concentrations of methane in the biogas, surpassing all other substrates from day 113 onwards, and providing significantly higher values up to 217 days of production in relation to the other substrates. 
TABLE 3. Data of average quantity of $\mathrm{CH}_{4}$ in $\%$ for each substract.

\begin{tabular}{lcccccccccccc}
\hline \multirow{2}{*}{ Substrate } & \multicolumn{10}{c}{ Days After Filling of the Biodigesters } \\
\cline { 2 - 13 } & 43 & 57 & 71 & 85 & 99 & 113 & 127 & 141 & 155 & 169 & 183 & 217 \\
\hline LB & 28.61 & 59.04 & 62.44 & 54.46 & 77.70 & 84.70 & 83.56 & 83.62 & 84.00 & 84.36 & 81.90 & 90.72 \\
GBL & 54.25 & 53.44 & 57.99 & 52.93 & 78.43 & 85.44 & 83.56 & 84.36 & 81.00 & 78.44 & 74.88 & 84.00 \\
BLWS & 36.42 & 60.57 & 68.03 & 73.29 & 77.70 & 78.01 & 74.03 & 74.74 & 63.00 & 56.24 & 61.62 & s/prod \\
GBLWS & 41.62 & 53.95 & 56.85 & 64.64 & 78.43 & 81.73 & 77.70 & 78.44 & 72.00 & 70.30 & 66.30 & s/prod \\
BLPH & 39.02 & 60.57 & 61.98 & 69.73 & 76.96 & 83.96 & 73.30 & 74.00 & 74.25 & 69.56 & 69.42 & 73.08 \\
GBLPH & 46.08 & 54.97 & 58.70 & 54.97 & 77.70 & 69.84 & 79.16 & 79.92 & 75.00 & 68.08 & 68.64 & s/prod \\
\hline
\end{tabular}

Litter of broiler (LB); Grinded broiler litter (GBL); Broiler litter with wood shavings (BLWS); Grinded broiler litter with wood shavings (GBLWS); Broiler litter with peanut hulls (BLPH); Grinded broiler litter with peanut hull (GBLPH).

Analyzing the data in Table 4, $\mathrm{CO}_{2}$ levels were higher at the beginning of the anaerobic fermentation in all substrates studied, with peaks of maximum production up to 71 days of anaerobic fermentation, and from 127 days onwards it appeared in smaller percentages, except in the substrate $\mathrm{LB}$, which also presented by the end of production higher $\mathrm{CO}_{2}$ levels in its biogas composition. Species of methanogenic bacteria produce methane, the gas with most reduced carbon in nature, via decarboxylation of acetate or by carbon dioxide reduction by hydrogen (VAZZOLA, 1993). At the beginning of the anaerobic fermentation there is not yet microorganism selection, so methanogenic bacteria are inefficient or even in smaller amount than $\mathrm{CO}_{2}$-producing species, which is consistent with SATHIANATHAN (1975), and besides, there is oxygen in the environment at significant levels for the process.

TABLE 4. Data of average quantity of $\mathrm{CO}_{2}$ in $\%$.

\begin{tabular}{lcccrrrrrrrrc}
\hline & \multicolumn{10}{c}{ Days After Filling of the Biodigesters } \\
\cline { 2 - 14 } Substrate & 43 & 57 & 71 & \multicolumn{1}{c}{85} & \multicolumn{1}{c}{114} & 113 & 127 & 141 & 155 & 169 & 183 & 217 \\
\hline LB & 13.1 & 28.0 & 28.0 & 17.5 & 14.0 & 7.0 & 8.7 & 8.7 & 4.3 & 5.8 & 5.0 & s/prod \\
GBL & 15.3 & 14.0 & 14.0 & 7.0 & 10.5 & 7.0 & 4.3 & 0.8 & 5.2 & s/prod & s/prod & s/prod \\
BLWS & 17.5 & 14.0 & 14.0 & 8.7 & 7.0 & 3.5 & 0.4 & 0.9 & s/prod & s/prod & s/prod & s/prod \\
GBLWS & 22.9 & 16.8 & 24.5 & 7.0 & 7.0 & 3.5 & 4.3 & 0.7 & s/prod & s/prod & s/prod & s/prod \\
BLPH & 15.3 & 16.8 & 14.0 & 7.0 & 14.0 & 4.3 & 0.4 & 1.0 & 0.8 & s/prod & s/prod & s/prod \\
GBLPH & 22.9 & 16.8 & 14.0 & 8.7 & 17.5 & 7.0 & 4.3 & 8.7 & 4.3 & s/prod & s/prod & s/prod \\
\hline
\end{tabular}

Litter of broiler (LB); Grinded broiler litter (GBL); Broiler litter with wood shavings (BLWS); Grinded broiler litter with wood shavings (GBLWS); Broiler litter with peanut hulls (BLPH); Grinded broiler litter with peanut hull $(\mathrm{GBLPH}) . \mathrm{s} / \mathrm{prod}=$ not detected

It appears that for each type of substrate, the concentration of $\mathrm{CO}_{2}$ varied in a different fashion, being that LB had higher levels until the end of biogas production, relative to GBL. In BLWS, there was less $\mathrm{CO}_{2}$ compared to GBLWS, with only one superior production at 85 days of production. For the substrate BLPH, it was noticed that $\mathrm{CO}_{2}$ production was at or below its corresponding ground substrate (GBLPH). The biogas produced by the substrates studied showed high levels of oxygen, as can be seen from Table 5 .

The data in Table 5 show that the percentage of $\mathrm{O}_{2}$ was higher at the beginning of the anaerobic process, and tended to decrease over time, remaining between 1.0 and $1.5 \%$ from day 113 onwards. All treatments produced biogas with similar levels of $\mathrm{O}_{2}$ and for each of the substrate samples. 
TABLE 5. Average quantity of $\mathrm{O}_{2}$ in $\%$ for each substract.

\begin{tabular}{lcccccccccccc}
\hline & \multicolumn{10}{c}{ Days After Filling of the Biodigesters } \\
\cline { 2 - 14 } Substrate & 43 & 57 & 71 & 85 & 99 & 113 & 127 & 141 & 155 & 169 & 183 & 217 \\
\hline LB & 1.8 & 0.9 & 1.5 & 2.7 & 2.0 & 1.5 & 1.5 & 1.3 & 1.5 & 1.5 & 1.4 & 1.0 \\
GBL & 2.3 & 2.6 & 2.3 & 2.7 & 2.0 & 1.5 & 1.5 & 1.6 & 1.2 & 1.0 & 1.1 & 1.2 \\
BLWS & 2.9 & 2.0 & 1.5 & 1.3 & 1.3 & 1.5 & 1.2 & 1.3 & 1.0 & 1.0 & 0.8 & s/prod \\
GBLWS & 2.8 & 2.3 & 2.3 & 2.2 & 2.0 & 1.5 & 1.5 & 1.3 & 1.0 & 1.0 & 0.8 & s/prod \\
BLPH & 2.4 & 1.3 & 2.2 & 1.3 & 2.0 & 1.5 & 1.4 & 0.9 & 1.0 & 1.0 & 1.4 & 1.0 \\
GBLPH & 2.4 & 2.3 & 2.3 & 2.7 & 2.0 & 1.0 & 1.5 & 1.6 & 1.0 & 1.0 & 0.8 & s/prod \\
\hline
\end{tabular}

Litter of broiler (LB); Grinded broiler litter (GBL); Broiler litter with wood shavings (BLWS); Grinded broiler litter with wood shavings (GBLWS); Broiler litter with peanut hulls (BLPH); Grinded broiler litter with peanut hull (GBLPH).

\section{CONCLUSIONS}

The substrate GBL presented the highest cumulative production of biogas than the other substrates, whereas BLWS presented the lowest cumulative production at the end of the period studied.

In general, the period of maximum production of biogas initiated between 45 and 60 days, and started to decline from 120 days after the filling of substrates to the digesters.

The ground substrates, due to higher specific surface of the particles, showed higher amount of accumulated biogas in relation to non-ground substrates, except for GBLPH, which showed 20.9 $\mathrm{m}^{3}$ less than the BLPH substrate.

At 57 days after the filling of the digesters, the gas produced showed more than $53 \%$ in methane levels.

From 99 days after filling of the digesters, all substrates produced biogas with methane content above $70 \%$.

The LB and GBL substrates showed high concentrations of methane in the biogas, providing significantly high values at the end of production.

\section{REFERENCES}

AMORIM, A.C.; LUCAS JÚNIOR, J.; RESENDE, K.T. Efeito da estação do ano sobre a biodigestão anaeróbia de dejetos de caprinos. Engenharia Agrícola, Jaboticabal, v.24, n.1, p.16-24, 2004.

BRASIL. MINISTÉRIO DAS MINAS E ENERGIA. Balanço Energético Nacional. 2005.

Disponível em: <http://www.mme.gov.br>. Acesso em: 2 jun. 2008.

ESPERANCINI, M.S.T.; COLEN, F.; BUENO, O.C.; PIMENTEL, A.E.B.; SIMON, E.J. Viabilidade técnica e econômica da substituição de fontes convencionais de energia por biogás em assentamento rural do Estado de São Paulo. Engenharia Agrícola, Jaboticabal, v.27, n.1, p.110-118, 2007.

GALBIATTI, J.A.; CARAMELO, A.D.; SILVA, F.G.; GERARDI, E.A.B.; CHICONATO, D.A. Estudo qualiquantitativo do biogás produzidos por substratos em biodigestores tipo batelada.

Revista Brasileira de Engenharia Agrícola e Ambiental, Campina Grande, v.14, n.4, p.432-437, 2010.

LORA, E.S.; ANDRADE, R.V. Biomass as energy source in Brazil. Renewable and Sustainable Energy Reviews, Oxford, v.13, p.777-788, 2009. 
LUNA, M.L.D. de; LEITE, V.D.; LOPES, W.S.; SOUZA, J.T. de; SILVA, S.A. Tratamento anaeróbio de resíduos orgânicos com baixa concentração de sólidos. Engenharia Agrícola, Jaboticabal, v.29, n.1, p.113-121, 2009.

ORRICO JÚNIOR, M.A.P.; ORRICO, A.C.A.; LUCAS JÚNIOR, J. Biodigestão anaeróbia dos resíduos da produção avícola: cama de frangos e carcaças. Engenharia Agrícola, Jaboticabal, v.30, n.3, p.546-554, 2010.

PRADO, M.A.C.; CAMPOS, C.M.M. Produção de biogás no tratamento dos efluentes líquidos do processamento de Coffea arabica L. em reator anaeróbico UASB para o potencial aproveitamento na secagem do café. Ciência e agrotecnologia, Lavras, v.32, n.3, p.938-947, 2008.

ROSS, C.C.; DRAKE, T.J.; WALSH, J.L. Handbook of biogas utilization. 2.ed. Atlanta: U.S. Department of Energy, 1996.

SALOMON, K.R.; LORA, E.E.S.; MONROY, E.F.C. Custo do biogás proveniente da vinhaça e sua utilização. In: CONGRESSO IBEROAMERICANO DE ENGENHARIA MECÂNICA, 8., 2007, Cusco. Anais...

SANTI, A.; CARVALHO, M.A.C; CAMPOS, O.R.; SILVA, A.F. da; ALMEIDA, J.L. de; MONTEIRO, S. Ação de material orgânico sobre a produção e características comerciais de cultivares de alface. Horticultura Brasileira, Brasília, v.28, n.1, p.87-90, 2010.

SATHIANATHAN, M.A. Biogas achievements challenges. New Delhi: Association of voluntary Agencies for Rural Development, 192. 1975 p.

SOUZA, O.; FEDERIZZI, M.; COELHO, B.; WAGNER, T.M.; WISBECK, E. Biodegradação de resíduos lignocelulósicos gerados na bananicultura e sua valorização para a produção de biogás. Revista Brasileira de Engenharia Agrícola e Ambiental, Campina Grande, v.14, n.4, p.438-443, 2010.

SOUZA, R.G.; SILVA, F.M.; BASTOS, A.C. Desempenho de um conjunto motogerador adaptado à biogás. Ciência e agrotecnologia, Lavras, v.34, n.1, p.190-195, 2010.

VAZOLLER, R.F. Características e interações microbianas nos processos de tratamento biológico aeróbio e anaeróbio. In: CURSO DE PROCESSOS BIOLÓGICOS DE TRATAMENTO DE RESÍDUOS, 2., 1993, São Paulo. Palestras... São Paulo: IPT, 1993. 18 p.

XAVIER, C.A.N.; LUCAS JÚNIOR, J. Parâmetros de dimensionamento para biodigestores batelada operados com dejetos de vacas leiteiras com e sem uso de inoculo. Engenharia Agrícola, Jaboticabal, v.30, n.2, p.212-223, 2010. 